\title{
SERUM LEVELS OF OXIDATIVE STRESS MARKERS IN SUBCLINICAL AND OVERT HYPOTHYROIDISM VERSUS CONTROL GROUP IN POPULATION OF KUTAHYA CITY, TURKEY
}

\author{
Mustafa Yontem', (DSerap Arslan², (iD Behic Selman Erdogdu', (DFatma Emel Kocak \\ Departments of ${ }^{1}$ Biotechnology \& ${ }^{3}$ Molecular Biology and Genetics, Faculty of Science, Necmettin Erbakan \\ University, Meram, Konya, ${ }^{2}$ Central Laboratory, Konya Meram State Hospital, Meram, Konya, ${ }^{4}$ Department of \\ Biochemistry, Faculty of Medicine, Kutahya University of Health Sciences, Kutahya, Turkey
}

\begin{abstract}
Background: Overproduction of oxygen-related free radicals and inadequate antioxidant defense are critical in hypothyroidism, as they might lead to future life-threatening diseases. The objectives of this study were to compare serum levels of oxidative stress markers; total oxidant status (TOS), total antioxidant status (TAS), oxidative stress index (OSI), paraoxonase-1 (PON-1), and arylesterase (ARYL) in patients with subclinical hypothyroidism (SH) and overt hypothyroidism $(\mathrm{OH})$ versus healthy controls in population of Kutahya city, Turkey.

Materials \& Methods: This cross-sectional study was conducted at Department of Biochemistry, Faculty of Medicine, Kutahya University of Health Sciences, Kutahya, Turkey, from July to December, 2016. Three study groups of 45 each were formed as healthy controls, patients with $\mathrm{SH}$ and $\mathrm{OH}$. Serum levels of TOS, TAS, OSI, PON-1, and ARYL were five research variables with ratio scale, but skewed, so described by median and IQR with $95 \% \mathrm{Cl}$. Kruskal-Wallis and multiple comparison tests were used for hypotheses testing.

Results: Serum levels of TOS and OSI were higher in SH group (p-values $0.032 ;<.0001$; respectively) and $\mathrm{OH}$ group ( $p$-values $<.0001 ;<.0001$, respectively) than healthy controls, while serum levels of TAS, PON-1 and ARYL were lower in SH group ( $p$-values $<.0001 ;<.0001 ;<.0001$, respectively) and $\mathrm{OH}$ group ( $\mathrm{p}$-values $<.0001$; $<.0001 ;<.0001$, respectively) than control group.

Conclusion: Our study showed that serum levels of TOS and OSI were higher in subclinical and overt hypothyroidism than in healthy controls; while serum levels of TAS, PON-1, and ARYL were lower in subclinical and overt hypothyroidism than in healthy controls.

KEY WORDS: Hypothyroidism; Thyroid Stimulating Hormone; Oxidants; Antioxidants; Oxidative Stress; Paraoxonase-1; Total Oxidant Status; Total Antioxidant Status; Oxidative Stress Index; Arylesterase.

Cite as: Yontem M, Arslan S, Erdogdu BS, Kocak FE. Serum levels of oxidative stress parameters in postmenopausal versus fertile women of Kutahya city, Turkey. Gomal J Med Sci 2021 Oct-Dec; 19(4):132-40. https://doi.org/10.46903/gjms/19.04.935
\end{abstract}

\section{INTRODUCTION}

1.1 Background: Hypothyroidism is a common metabolic disorder characterized by a slowed

\section{Corresponding Author:}

Mustafa Yontem

Associate Professor

Department of Biotechnology, Faculty of Science

Necmettin Erbakan University, Meram, Konya

Turkey

E-mail: myontem@erbakan.edu.tr

$\begin{array}{ll}\text { Date Submitted: } & 06-08-2020 \\ \text { Date Revised: } & 13-07-2021 \\ \text { Date Accepted: } & 17-08-2021\end{array}$ metabolism caused by low thyroid hormone levels in the blood. Overt hypothyroidism $(\mathrm{OH})$ is defined by lower serum thyroid hormone levels and higher thyroid stimulating hormone (TSH) levels than the normal ranges. Subclinical hypothyroidism $(\mathrm{SH})$ occurs when TSH levels are elevated, while serum thyroid hormone levels are within the normal range. ${ }^{1}$ $\mathrm{SH}$ is a growing global public health problem that affects $4-20 \%$ of the adult population and has an even higher incidence than diabetes. ${ }^{2}$ Many metabolic parameters are regulated by thyroid hormones, thus the alterations in the secretion of TSH and thyroid hormones affects various systems, including the musculoskeletal, respiratory, gastrointestinal, nervous and cardiovascular systems. 
The imbalance between the oxidant and antioxidant defense mechanisms is known as oxidative stress and the oxidative stress index (OSI) is calculated by dividing total oxidant status (TOS) $(\mu \mathrm{mol} \mathrm{H} 2 \mathrm{O} 2$ equivalent/L) to total antioxidant status (TAS) ( $\mathrm{mmol}$ Trolox equivalent/L). ${ }^{7}$ Overproduction of reactive oxygen species or failure of various antioxidant defense systems cause molecular dysfunction by oxidizing macromolecules like carbohydrates, lipids, and proteins. ${ }^{8}$ Due to slowing down effects on the metabolism, free radical production is expected at low rates in $\mathrm{OH}^{9,10}$ Contrary to this, some researchers have revealed that oxidative stress is elevated in $\mathrm{OH}^{.}{ }^{11-13}$ It seems that the values of the $\mathrm{OSI}$ in $\mathrm{OH}$ and $\mathrm{SH}$ are important in providing information about the status of antioxidant defense in hypothyroidism.

Paraoxonases (PON) are an enzyme family, consisting of three members; PON-1, PON-2, and PON-3. Both PON-1 and PON-3 have antioxidant and anti-inflammatory properties. ${ }^{14} \mathrm{PON}-1$ has a protective role by hydrolysing lipid peroxides of oxidized lipoproteins. ${ }^{15-17}$ In addition, as a result of increased oxidative stress, reduced PON-1 activities are reported in many disorders such as diabetes, hypercholesterolemia, and cardiovascular disease. ${ }^{18-20}$ Moreover, PON-1 plays an important role in enzymatic antioxidant defense with arylesterase (ARYL) which has a similar function with PON-1. ${ }^{21}$

\subsection{Research Objectives (ROs)}

RO 1-5: To analyze the serum levels of oxidative stress markers; TOS, TAS, OSI, PON-1 \& ARYL in control, $\mathrm{SH}$, and $\mathrm{OH}$ groups

RO 6-10: To compare the serum levels of oxidative stress markers; TOS, TAS, OSI, PON-1 \& ARYL in $\mathrm{SH}$ and $\mathrm{OH}$ versus control group.

\subsection{Research (Null) Hypotheses (RHs)}

$\mathbf{H}_{01}$ : Serum level of TOS is same in $\mathrm{SH}$ as control group in population of Kutahya city, Turkey.

$\mathbf{H}_{02}$ : Serum level of TOS is same in $\mathrm{OH}$ as control group in population of Kutahya city, Turkey.

$\mathbf{H}_{03}$ : Serum level of TAS is same in SH and control group in population of Kutahya city, Turkey.

$\mathbf{H}_{04}$ : Serum level of TAS is same in $\mathrm{OH}$ as control group in population of Kutahya city, Turkey.

$\mathbf{H}_{05}$ : Serum level of OSI is same in $\mathrm{SH}$ and control group in population of Kutahya city, Turkey.

$\mathbf{H}_{06}$ : Serum level of $\mathrm{OSI}$ is same in $\mathrm{OH}$ as control group in population of Kutahya city, Turkey.

$\mathbf{H}_{07}$ : Serum level of PON-1 is same in $\mathrm{SH}$ as control group in population of Kutahya city, Turkey.

$\mathbf{H}_{08}$ : Serum level of PON-1 is same in $\mathrm{OH}$ as control group in population of Kutahya city, Turkey.

$\mathbf{H}_{09}$ : Serum level of ARYL is same in $\mathrm{SH}$ as control group in population of Kutahya city, Turkey.
$\mathbf{H}_{010}$ : Serum level of ARYL is same in $\mathrm{OH}$ as control group in population of Kutahya city, Turkey.

\section{MATERIALS \& METHODS}

2.1 Design, Duration \& Setting: From July to December 2016, this sectional study was conducted in the Department of Biochemistry, Faculty of Medicine, Kutahya University of Health Sciences, Kutahya, Turkey. The samples were selected from the Department of Medical Biochemistry, Evliya Celebi Research and Education Hospital, Kutahya, Turkey. The Declaration of Helsinlevelski's guidelines were followed. Ethical committee approval was granted by the local Human Research Ethics Committee. Written informed consent was obtained from all subjects.

2.2 Population \& sampling: Kutahya city is in the western part of Turkey with assumed population of 450,000 for the year 2016. Three samples each of 50 adult subjects were selected from this population as group 1 healthy control, group $2 \mathrm{SH}$ and group $3 \mathrm{OH}$ cases.

Clinically and laboratory confirmed new cases of $\mathrm{SH}$ and $\mathrm{OH}$ were included. Exclusion criteria were as follows: thyroid hormone therapy in past, alcoholism, smoking, existence of chronic medical illness, chronic pharmacological therapy, usage of supplemental multivitamins, minerals and antioxidants.

$\mathrm{SH}$ was diagnosed by high serum TSH level (>5.6 $\mathrm{mlU} / \mathrm{mL}$ ) associated with normal fT4 level. $\mathrm{OH}$ was diagnosed by high TSH level associated with low fT4 level $(<0.34 \mathrm{mlU} / \mathrm{mL})$.

\subsection{Collection of blood samples and analysis of laboratory parameters}

\subsubsection{Blood sample collection}

Biochemical studies were performed on venous blood samples. Blood samples were centrifuged at $\mathrm{x} 1500 \mathrm{~g}$ for 15 minutes. Serum samples were stored at $-80^{\circ} \mathrm{C}$ for TAS, TOS, PON-1, and ARYL assays.

\subsubsection{Measurement of serum TAS and TOS levels}

Serum TAS and TOS levels were measured ysing Erel's new automated analysis technologies.

TAS levels were expressed in millimoles of Trolox equivalent per liter. TOS levels were expressed in $\mu$ mol $\mathrm{H}_{2} \mathrm{O}_{2}$ equivalent per liter.

\subsubsection{Calculation of OSI}

The OSI was established as a measure of oxidative stress based on the percent ratio of TOS to TAS. The OSI was calculated as follows: OSI $=[($ TOS, $\left.\mu \mathrm{mol} \mathrm{H}_{2} \mathrm{O}_{2} \mathrm{Eq} / \mathrm{L}\right) /\left(\mathrm{TAS}, \mu \mathrm{mol}\right.$ Trolox Eq/L) x 100]. ${ }^{24}$ OSI values were expressed as arbitrary units (AU).

\subsubsection{Measurement of serum PON-1 and ARYL activities}

PON-1 and ARYL activity in the serum were analyzed using Erel's automated measurement methods. ${ }^{25,26}$ The activity of PON-1 and ARYL in the serum were expressed in units per liter (U/L). 


\subsubsection{Measurement of serum fT4 and TSH levels}

The chemiluminescent immunoassay method was used to quantify serum fT4 and TSH levels. TSH: 0.34-5.6 $\mathrm{mIU} / \mathrm{mL}$, fT4: $7.85-14.41 \mathrm{pmol} / \mathrm{L}$, were the reference values in healthy individuals.

\subsection{Data collection \& data analysis plan}

\subsubsection{Descriptive statistics \& estimation of pa- rameters}

Five research variables were serum TOS, TAS, and OSI levels, as well as PON-1 and ARYL activity. The data type for these variables was ratio (numeric). The skewness, kurtosis, coefficient of variation percent (CV percent), and Shapiro-Wilk (SW) tests were used to determine normality. SW test statistics (W) and $\mathrm{p}$-values were presented. As all data was skewed, so it was analyzed by median (Q2), quartile 1 (Q1), Q3, interquartile range $(I Q R=Q 3-Q 1)$ with $95 \% \mathrm{Cl}$ for median.

\subsubsection{Hypotheses testing}

The comparisons of data for five variables between the three study groups was done by the Kruskal-Wallis test because all data was skewed (not normally distributed). Sample sizes, medians, mean ranks, Kruskal-Wallis $\mathrm{H}$, degree of freedom, and significance ( $p$-value) are given for each test. In next step, pairwise comparisons are done giving us the significance of difference between the pairs; healthy controls and $\mathrm{SH}$ and healthy controls and $\mathrm{OH}$, showing mean ranks, test statistic, standard error (SE) and p-value for each test at alpha 0.05 . The data were analyzed by IBM SPSS for Windows, version 22.0 (IBM Corp., Armonk, New York).

\section{RESULTS}

3.1 Tests of Normality: Table 3.1 displays the results, along with an interpretation based on the five tests. All variables are interpreted as skewed.

3.2 Descriptive statistics \& estimation of parameters: The mean \pm SD age was $45.7 \pm 8.2$ years for group 1 (control group), $47.1 \pm 6.6$ years for group 2 subclinical hypothyroidism ( $\mathrm{SH})$, and $46.4 \pm 7.9$ years for group 3 overt hypothyroidism $(\mathrm{OH})$.

Table 3.1: Normality tests for serum levels of oxidative stress markers in individuals with no hypothyroidism $(n 1=45)$, subclinical hypothyroidism $(n 2=45)$, and overt hypothyroidism $(n 3=45)$ in Kutahya city, Turkey.

\begin{tabular}{|c|c|c|c|c|c|c|c|}
\hline Variables & Groups & Skewness & Kurtosis & CV \% & W & $p$-value & Data distribution \\
\hline \multirow{3}{*}{$\begin{array}{l}\text { TOS } \\
(\mu \mathrm{mol} \mathrm{H} 2 \mathrm{O} 2 \\
\text { Eq./L) }\end{array}$} & Control & 0.606 & -0.181 & 28.78 & 0.961 & .127 & Normal \\
\hline & $\mathrm{SH}$ & 2.134 & 6.211 & 64.41 & 0.789 & $<.0001$ & Skewed \\
\hline & $\mathrm{OH}$ & 2.136 & 5.220 & 59.66 & 0.7807 & $<.0001$ & Skewed \\
\hline \multirow{3}{*}{$\begin{array}{l}\text { TAS } \\
\text { (mmol Trolox } \\
\text { Eq./L) }\end{array}$} & Control & 1.722 & 2.900 & 25.66 & 0.781 & $<.0001$ & Skewed \\
\hline & $\mathrm{SH}$ & 0.768 & 0.083 & 10.54 & 0.945 & .032 & Skewed \\
\hline & $\mathrm{OH}$ & -0.425 & -0.993 & 27.33 & 0.9335 & .012 & Skewed \\
\hline \multirow{3}{*}{$\begin{array}{l}\text { OSI } \\
\text { (Arbitrary Unit) }\end{array}$} & Control & 1.108 & 1.722 & 37.36 & 0.915 & .003 & Skewed \\
\hline & $\mathrm{SH}$ & 0.834 & 0.853 & 35.23 & 0.935 & .014 & Skewed \\
\hline & $\mathrm{OH}$ & 1.314 & 1.803 & 42.64 & 0.888 & .0004 & Skewed \\
\hline \multirow{3}{*}{ PON-1 (U/L) } & Control & -0.269 & -0.498 & 34.90 & 0.961 & .129 & Normal \\
\hline & $\mathrm{SH}$ & 0.558 & -0.505 & 43.33 & 0.948 & .042 & Skewed \\
\hline & $\mathrm{OH}$ & 2.007 & 3.946 & 47.15 & 0.769 & $<.0001$ & Skewed \\
\hline \multirow{3}{*}{ ARYL (U/L) } & Control & 0.154 & -0.773 & 18.42 & 0.973 & .358 & Normal \\
\hline & $\mathrm{SH}$ & -0.809 & 1.328 & 23.58 & 0.956 & .087 & Normal \\
\hline & $\mathrm{OH}$ & -0.086 & -1.414 & 29.14 & 0.922 & .005 & Skewed \\
\hline
\end{tabular}

$\mathrm{CV} \%=$ Coefficient of variation $\%, \mathrm{~W}=$ Shapiro-Wilk statistics, $\mathrm{SH}=$ Subclinical hypothyroidism group, $\mathrm{OH}=$ Overt hypothyroidism group 
Table 3.2 shows serum levels of oxidative stress markers in control, subclinical and overt hypothyroidism. The median serum levels of TOS and OSI are higher in $\mathrm{SH}$ and $\mathrm{OH}$ groups than control group, while those of TAS, PON-1 and ARYL are lower in SH and $\mathrm{OH}$ groups than control group.

\subsection{Hypotheses Testing}

3.3.1 TOS levels in control, $\mathrm{SH} \& \mathrm{OH}\left(\mathrm{H}_{01} \& \mathrm{H}_{02}\right)$ : The difference of median level of TOS between the control, $\mathrm{SH}$ and $\mathrm{OH}$ groups was testified by Kruskal-Wallis test. The difference was statistically significant with a p-value of $<.0001$. (Table 3.3.1.1)

Table 3.2: Serum levels of oxidative stress markers in individuals with no hypothyroidism $(n 1=45)$, subclinical hypothyroidism $(n 2=45)$, and overt hypothyroidism $(n 3=45)$ in Kutahya city, Turkey.

\begin{tabular}{|c|c|c|c|c|c|c|c|}
\hline \multirow{2}{*}{ Variables } & \multirow{2}{*}{ Groups } & \multicolumn{4}{|c|}{ Sample statistics } & \multicolumn{2}{|c|}{$95 \% \mathrm{Cl}$ for median } \\
\hline & & Quartile 1 (Q1) & Median (Q2) & Quartile 3 (Q3) & IQR & Lower & Upper \\
\hline \multirow{3}{*}{$\begin{array}{l}\text { TOS } \\
(\mu \mathrm{mol} \mathrm{H} 2 \mathrm{O} 2 \\
\text { Eq./L) }\end{array}$} & Control & 3.645 & 4.410 & 5.700 & 2.055 & 4.060 & 5.130 \\
\hline & $\mathrm{SH}$ & 3.755 & 5.260 & 8.385 & 4.630 & 4.170 & 6.880 \\
\hline & $\mathrm{OH}$ & 5.325 & 7.040 & 10.23 & 4.905 & 6.080 & 8.320 \\
\hline \multirow{3}{*}{$\begin{array}{l}\text { TAS } \\
\text { (mmol Trolox } \\
\text { Eq./L) }\end{array}$} & Control & 1.670 & 1.800 & 2.425 & 0.755 & 1.700 & 1.870 \\
\hline & $\mathrm{SH}$ & 1.455 & 1.540 & 1.685 & 0.230 & 1.490 & 1.620 \\
\hline & $\mathrm{OH}$ & 0.890 & 1.250 & 1.385 & 0.495 & 1.010 & 1.340 \\
\hline \multirow{3}{*}{ OSI (Arbitrary Unit) } & Control & 0.220 & 0.300 & 0.390 & 0.170 & 0.250 & 0.360 \\
\hline & $\mathrm{SH}$ & 0.390 & 0.520 & 0.693 & 0.303 & 0.416 & 0.636 \\
\hline & $\mathrm{OH}$ & 0.475 & 0.640 & 0.890 & 0.415 & 0.540 & 0.740 \\
\hline \multirow{3}{*}{ PON-1 (U/L) } & Control & 253.5 & 325.0 & 372.5 & 119.0 & 282.0 & 349.0 \\
\hline & $\mathrm{SH}$ & 144.0 & 172.0 & 263.5 & 119.5 & 154.0 & 237.0 \\
\hline & $\mathrm{OH}$ & 100.5 & 116.0 & 143.5 & 43.0 & 103.0 & 131.0 \\
\hline \multirow{3}{*}{ ARYL (U/L) } & Control & 537.0 & 613.0 & 710.5 & 173.5 & 558.0 & 668.0 \\
\hline & $\mathrm{SH}$ & 382.5 & 454.0 & 539.0 & 156.5 & 430.0 & 509.0 \\
\hline & $\mathrm{OH}$ & 274.0 & 374.0 & 504.5 & 230.5 & 325.0 & 471.0 \\
\hline
\end{tabular}

$\mathrm{Q}=$ Quartile, IQR=Inter quartile range (Q3-Q1), $\mathrm{Cl}=$ Confidence Interval, $\mathrm{SH}=$ Subclinical hypothyroidism group, $\mathrm{OH}=$ Overt hypothyroidism group

Table 3.3.1.1: Serum levels of TOS in control, subclinical (SH) and overt hypothyroidism (OH) in population of Kutahya city, Turkey

\begin{tabular}{|l|l|l|l|l|l|l|l|}
\hline Variable & Groups & $\mathrm{N}$ & Median & Mean Rank & Kruskal-Wallis H & d.f. & p-value (2-tailed) \\
\hline TOS & Control & 45 & 4.410 & 48.57 & & & \\
\cline { 1 - 4 } & $\mathrm{SH}$ & 45 & 5.260 & 66.22 & \multirow{2}{*}{24.433} & 2 & $<.0001$ \\
\cline { 2 - 5 } & $\mathrm{OH}$ & 45 & 7.040 & 89.21 & & & \\
\hline
\end{tabular}

$Q=$ Quartile, IQR $=$ Interquartile range, d.f. $=$ Degree of freedom 
Multiple comparison tests revealed a statistically significant difference between the control and $\mathrm{SH}$ groups, as well as the control and $\mathrm{OH}$ groups, indicating that the median levels of TOS in $\mathrm{SH}$ and $\mathrm{OH}$ are much greater than the control group. (Table 3.3.1.2)

3.3.2 TAS levels in control, $\mathrm{SH} \& \mathrm{OH}\left(\mathrm{H}_{03} \& \mathrm{H}_{04}\right)$ : The difference of median level of TAS between the control, $\mathrm{SH}$ and $\mathrm{OH}$ groups was testified by Kruskal-Wallis test. The difference was statistically significant with a p-value of <.0001. (Table 3.3.2.1)
Multiple comparison tests revealed a statistically significant difference between the control and $\mathrm{SH}$ groups, as well as the control and $\mathrm{OH}$ groups, indicating that the median TAS levels in $\mathrm{SH}$ and $\mathrm{OH}$ are significantly lower than the control group. (Table 3.3.2.2)

3.3.3 OSI level in control, $\mathrm{SH} \& \mathrm{OH}\left(\mathbf{H}_{05} \& \mathbf{H}_{06}\right)$ : The difference of median level of OSI between the control, $\mathrm{SH}$ and $\mathrm{OH}$ groups were testified by Kruskal-Wallis test. The difference was statistically significant with a p-value of $<.0001$. (Table 3.3.3.1)

Table 3.3.1.2: Serum levels of TOS in subclinical (SH) vs. control and in overt hypothyroidism (OH) vs. control in population of Kutahya city, Turkey

\begin{tabular}{|c|c|c|c|c|c|c|}
\hline Groups & $\mathrm{N}$ & Mean Rank & Test statistic & Stand. Error & $p$-value & Decision \\
\hline Control group & 45 & 48.57 & \multirow{2}{*}{-17.65} & \multirow{2}{*}{8.246} & \multirow{2}{*}{.032} & \multirow{2}{*}{$\mathrm{H}_{01}$ rejected } \\
\hline SH group & 45 & 66.22 & & & & \\
\hline Control group & 45 & 48.57 & \multirow{2}{*}{-40.64} & \multirow{2}{*}{8.246} & \multirow{2}{*}{$<.0001$} & \multirow{2}{*}{$\mathrm{H}_{02}$ rejected } \\
\hline $\mathrm{OH}$ group & 45 & 89.21 & & & & \\
\hline
\end{tabular}

Table 3.3.2.1: Serum levels of TAS in control, subclinical (SH) and overt hypothyroidism $(\mathrm{OH})$ in population of Kutahya city, Turkey

\begin{tabular}{|l|l|l|c|c|c|c|c|}
\hline Variable & Groups & $\mathrm{N}$ & Median & Mean Rank & Kruskal-Wallis H & d.f. & p-value (2-tailed) \\
\hline \multirow{3}{*}{ TAS (mmol Trolox Eq./L) } & Control & 45 & 1.800 & 103.90 & & & \\
\cline { 2 - 6 } & $\mathrm{SH}$ & 45 & 1.540 & 71.16 & \multirow{2}{*}{83.083} & 2 & $<.0001$ \\
\cline { 2 - 6 } & $\mathrm{OH}$ & 45 & 1.250 & 28.94 & & & \\
\hline
\end{tabular}

$Q=$ Quartile, IQR = Interquartile range, d.f. = Degree of freedom

Table 3.3.2.2: Serum levels of TAS in subclinical (SH) vs. control and in overt hypothyroidism (OH) vs. control in population of Kutahya city, Turkey

\begin{tabular}{|l|c|c|c|c|c|c|}
\hline Groups & $\mathrm{N}$ & Mean Rank & Test statistic & Stand. Error & $\mathrm{p}$-value & Decision \\
\hline Control group & 45 & 103.90 & \multirow{2}{*}{32.74} & 8.245 & $<.0001$ & $\mathrm{H}_{03}$ rejected \\
\cline { 1 - 3 } SH group & 45 & 71.16 & & & & \\
\cline { 1 - 3 } Control group & 45 & 103.90 & \multirow{2}{*}{74.96} & 8.245 & $<.0001$ & $\mathrm{H}_{04}$ rejected \\
\cline { 1 - 3 } OH group & 45 & 28.94 & & & \\
\hline
\end{tabular}

Table 3.3.3.1: Serum levels of OSI in control, subclinical (SH) and overt hypothyroidism $(\mathrm{OH})$ in population of Kutahya city, Turkey

\begin{tabular}{|l|l|l|c|c|c|c|c|}
\hline Variable & Groups & $\mathrm{N}$ & Median & Mean Rank & Kruskal-Wallis H & d.f. & p-value (2-tailed) \\
\hline \multirow{3}{*}{ OSI (Arbitrary Unit) } & Control & 45 & 0.300 & 32.54 & & & \\
\cline { 2 - 6 } & $\mathrm{SH}$ & 45 & 0.520 & 76.54 & \multirow{2}{*}{60.437} & 2 & $<.0001$ \\
\cline { 2 - 6 } & $\mathrm{OH}$ & 45 & 0.640 & 94.91 & & & \\
\hline
\end{tabular}

$Q=$ Quartile, IQR = Interquartile range, $d . f=$ Degree of freedom 
Multiple comparison tests revealed a statistically significant difference between the control and $\mathrm{SH}$ groups, as well as the control and $\mathrm{OH}$ groups, indicating that the median OSI levels in $\mathrm{SH}$ and $\mathrm{OH}$ are significantly higher than the control group. (Table 3.3.3.2)

3.3.4 PON-1 level in control, SH \& OH $\left(\mathrm{H}_{07} \& \mathrm{H}_{08}\right)$ : The difference of median level of $\mathrm{PON}-1$ between the control, $\mathrm{SH}$ and $\mathrm{OH}$ groups was testified by Kruskal-Wallis test. The difference was statistically significant with a p-value of <.0001. (Table 3.3.4.1)
Multiple comparison tests revealed a statistically significant difference between the control and $\mathrm{SH}$ groups, as well as the control and $\mathrm{OH}$ groups, indicating that the median levels of $\mathrm{PON}-1$ in $\mathrm{SH}$ and $\mathrm{OH}$ are significantly lower than the control group. (Table 3.3.4.2)

3.3.5 ARYL level in control, SH \& OH $\left(\mathrm{H}_{09} \& \mathrm{H}_{010}\right)$ : The difference of median level of ARYL between the control, $\mathrm{SH}$ and $\mathrm{OH}$ groups was testified by Kruskal-Wallis test. The difference was statistically significant with a p-value of <.0001. (Table 3.3.5.1)

Table 3.3.3.2: Serum levels of OSI in subclinical (SH) vs. control and in overt hypothyroidism (OH) vs. control in population of Kutahya city, Turkey

\begin{tabular}{|c|c|c|c|c|c|c|}
\hline Groups & $\mathrm{N}$ & Mean Rank & Test statistic & Stand. Error & $\mathrm{p}$-value & Decision \\
\hline Control group & 45 & 32.54 & \multirow{2}{*}{-44.00} & \multirow{2}{*}{8.245} & \multirow{2}{*}{$<.0001$} & \multirow{2}{*}{$\mathrm{H}_{05}$ rejected } \\
\hline SH group & 45 & 76.54 & & & & \\
\hline Control group & 45 & 32.54 & \multirow{2}{*}{-62.37} & \multirow{2}{*}{8.245} & \multirow{2}{*}{$<.0001$} & \multirow{2}{*}{$\mathrm{H}_{06}$ rejected } \\
\hline $\mathrm{OH}$ group & 45 & 94.91 & & & & \\
\hline
\end{tabular}

Table 3.3.4.1: Serum levels of PON-1 in control, subclinical (SH) and overt hypothyroidism (OH) in population of Kutahya city, Turkey

\begin{tabular}{|l|l|c|c|c|c|c|c|}
\hline Variable & Groups & $\mathrm{N}$ & Median & Mean Rank & Kruskal- Wallis H & d.f. & p-value (2- tailed) \\
\hline \multirow{3}{*}{ PON-1 (U/L) } & Control & 45 & 325.0 & 99.11 & & & \\
\cline { 2 - 5 } & $\mathrm{SH}$ & 45 & 172.0 & 66.22 & \multirow{2}{*}{53.872} & 2 & $<.0001$ \\
\cline { 2 - 6 } & $\mathrm{OH}$ & 45 & 116.0 & 38.67 & & & \\
\hline
\end{tabular}

$\mathrm{Q}=$ Quartile, IQR $=$ Interquartile range, d.f. $=$ Degree of freedom

Table 3.3.4.2: Serum levels of PON-1 in subclinical (SH) vs. control and in overt hypothyroidism (OH) vs. control in population of Kutahya city, Turkey

\begin{tabular}{|c|c|c|c|c|c|c|}
\hline Groups & $\mathrm{N}$ & Mean Rank & Test statistic & Stand. Error & $\mathrm{p}$-value & Decision \\
\hline Control group & 45 & 99.11 & \multirow{2}{*}{32.89} & \multirow{2}{*}{8.246} & \multirow{2}{*}{$<.0001$} & \multirow{2}{*}{$\mathrm{H}_{07}$ rejected } \\
\hline SH group & 45 & 66.22 & & & & \\
\hline Control group & 45 & 99.11 & \multirow{2}{*}{60.44} & \multirow{2}{*}{8.246} & \multirow{2}{*}{$<.0001$} & \multirow{2}{*}{$\mathrm{H}_{08}$ rejected } \\
\hline $\mathrm{OH}$ group & 45 & 38.67 & & & & \\
\hline
\end{tabular}

Table 3.3.5.1: Serum levels of ARYL in control, subclinical (SH) and overt hypothyroidism (OH) in population of Kutahya city, Turkey

\begin{tabular}{|l|l|c|c|c|c|c|c|}
\hline Variable & Groups & N & Median & Mean Rank & Kruskal- Wallis H & d.f. & p-value (2- tailed) \\
\hline \multirow{3}{*}{ ARYL (U/L) } & Control & 45 & 613.0 & 102.33 & & & \\
\cline { 2 - 5 } & SH & 45 & 454.0 & 60.40 & \multirow{2}{*}{57.391} & 2 & $<.0001$ \\
\cline { 2 - 5 } & $\mathrm{OH}$ & 45 & 374.0 & 41.27 & & & \\
\hline
\end{tabular}

$\mathrm{Q}=$ Quartile, IQR = Interquartile range, d.f. = Degree of freedom 
Table 3.3.5.2: Serum levels of ARYL in subclinical (SH) vs. control and in overt hypothyroidism (OH) vs. control in population of Kutahya city, Turkey

\begin{tabular}{|c|c|c|c|c|c|c|}
\hline Groups & $\mathrm{N}$ & Mean Rank & Test statistic & Stand. Error & $p$-value & Decision \\
\hline Control group & 45 & 102.33 & \multirow{2}{*}{41.93} & \multirow{2}{*}{8.246} & \multirow{2}{*}{$<.0001$} & \multirow{2}{*}{$\mathrm{H}_{09}$ rejected } \\
\hline SH group & 45 & 60.40 & & & & \\
\hline Control group & 45 & 102.33 & \multirow{2}{*}{61.06} & \multirow{2}{*}{8.246} & \multirow{2}{*}{$<.0001$} & \multirow{2}{*}{$\mathrm{H}_{010}$ rejected } \\
\hline $\mathrm{OH}$ group & 45 & 41.27 & & & & \\
\hline
\end{tabular}

Multiple comparison tests revealed a statistically significant difference between the control and $\mathrm{SH}$ groups, as well as the control and $\mathrm{OH}$ groups, indicating that the median levels of ARYL in $\mathrm{SH}$ and $\mathrm{OH}$ are significantly lower than the control group. (Table 3.3.5.2)

\section{DISCUSSION}

4.1 TOS levels in control, $\mathrm{SH} \& \mathrm{OH}\left(\mathrm{H}_{01} \& \mathrm{H}_{02}\right)$ : Our study showed that median serum levels of TOS $(\mu \mathrm{mol}$ $\mathrm{H} 2 \mathrm{O} 2 \mathrm{Eq} . / \mathrm{L})$ are significantly higher in the $\mathrm{SH}$ (5.260, $p=0.032)$ and $\mathrm{OH}(7.040, p=<.0001)$ groups as compared to healthy control (4.410). (Table 3.3.1.2) Studies focused on Hashimoto's thyroiditis (a different thyroid disorder) reported that serum level of TOS was increased. ${ }^{26,27}$ Aydogdu, et al.$^{28}$ found that serum level of TOS was significantly higher in $\mathrm{SH}$ than healthy controls.

4.2 TAS levels in control, $\mathrm{SH} \& \mathrm{OH}\left(\mathrm{H}_{03} \& \mathrm{H}_{04}\right)$ : Our study showed that median serum levels of TAS (mmol Trolox Eq./L) are significantly lower in the $\mathrm{SH}(1.540, \mathrm{p}=<.0001)$ and $\mathrm{OH}(1.250, \mathrm{p}=<.0001)$ groups as compared to healthy control (1.800). (Table 3.3.2.2)

Ates, et al. have reported in their different studies that Hashimoto's thyroiditis patients had decreased serum TAS levels. ${ }^{26,27}$ Aydogdu, et al. ${ }^{28}$ indicated that serum level of TAS was lower in $\mathrm{SH}$ patients as compared to healthy controls.

4.3 OSI levels in control, $\mathrm{SH} \& \mathrm{OH}\left(\mathrm{H}_{05} \& \mathrm{H}_{06}\right)$ : Our study showed that median serum levels of OSI (Arbitrary Unit) are significantly higher in the $\mathrm{SH}(0.520$, $\mathrm{p}=<.0001)$ and $\mathrm{OH}(0.640, \mathrm{p}=.0001)$ groups as compared to healthy controls (0.300). (Table 3.3.3.2)

Oxidative stress is measured by investigating numerous oxidative stress markers, including TOS and TAS. Many researchers have indicated in prior studies that OSI is increased in Hashimoto's thyroiditis ${ }^{26,27}$ and $\mathrm{SH}$ patients ${ }^{28}$ when compared to healthy controls.

4.4 PON-1 activities in control, $\mathrm{SH} \& \mathrm{OH}\left(\mathrm{H}_{07}\right.$ \& $\mathbf{H}_{08}$ ): Our study showed that median serum activities of PON-1 (U/L) are significantly lower in the $\mathrm{SH}(172.0, \mathrm{p}=<.0001)$ and $\mathrm{OH}(116.0, \mathrm{p}=<.0001)$ groups as compared to healthy controls (325.0). (Table 3.3.4.2)

PON-1, an antioxidant enzyme on HDL-cholesterol, is known to protect HDL-cholesterol and LDL-cholesterol against peroxidation caused by free radicals. ${ }^{17}$

Serum PON-1 activities have previously been found to be lower in SH patients compared to healthy controls. ${ }^{18,29,30}$

The mechanism of lower PON-1 activity in hypothyroidism is still unclear; it is thought that it might be a result of increased oxidized lipid levels and ROS, which inhibit PON-1 activity. Furthermore, it has been reported that PON-1 activity is also reduced in a variety of metabolic disorders as a result of ROS pathogenesis associated with oxidative stress and inflammation. ${ }^{18}$

4.5 ARYL activities in control, SH \& OH $\left(\mathrm{H}_{09} \& \mathrm{H}_{010}\right)$ : Our study showed that median serum activities of ARYL (U/L) are significantly lower in the SH (454.0, $\mathrm{p}=<.0001)$ and $\mathrm{OH}(374.0, \mathrm{p}=<.0001)$ groups as compared to healthy controls (613.0). (Table 3.3.5.2)

ARYL, a PON-1-related antioxidant enzyme and oxidative stress marker, was found significantly lower in $\mathrm{SH}$ patients than in healthy subjects..$^{29,30}$

\section{CONCLUSIONS}

Our study showed that serum levels of TOS and OSI were higher in subclinical and overt hypothyroidism than in healthy controls; while serum levels of TAS, PON-1, and ARYL were lower in subclinical and overt hypothyroidism than in healthy controls.

The oxidative stress profile is increased and the antioxidant defense is weakened in patients with both subclinical and overt hypothyroidism. Reduced PON-1 and ARYL activities can lead to a lack of protection against lipid peroxidation and DNA oxidative damage, exposing patients at risk for future cardiovascular problems or cancer.

As things stand, we believe that oxidative stress and an unbalanced oxidant/ antioxidant defense are serious health issue in hypothyroidism, with the potential to induce a variety of illnesses, some of which are life-threatening. On the basis of these findings, we can conclude that $\mathrm{OH}$ and $\mathrm{SH}$ are linked 
to an increase in oxidative stress. Overproduction of reactive oxygen species (ROS) and a lack of antioxidant defense contribute to oxidative stress, a critical stage in metabolic disorders that can lead to mortality. Further studies in larger populations are needed to better understand the prognosis and risk factors of hypothyroidism, including age, sex, ethnicity, regional variations, nutritional habits, and so on.

Acknowledgement: We highly acknowledge the grant of permission by Dr. Muhammad Marwat (marwatmuhammad@gmail.com) from Gomal Medical College, D.I.Khan, Pakistan to use his innovated "Marwat's Logical Trajectory of Research Process" in our project and further his help in data analysis and report writing."

\section{REFERENCES}

1. Biondi B, Cappola AR, Cooper DS. Subclinical hypothyroidism: a review. JAMA 2019;322:15360. https://doi.org/10.1001/jama.2019.9052

2. Zha K, Zuo C, Wang A, Zhang B, Zhang Y, Wang $B$, et al. LDL in patients with subclinical hypothyroidism shows increased lipid peroxidation. Lipids Health Dis 2015;14:95. https://doi.org/10.1186/ s12944-015-0092-4

3. O"Brien T, Dinneen SF, O"Brien PC, Palumbo PJ. Hyperlipidemia in patients with primary and secondary hypothyroidism. Mayo Clin Proc 1993;68:860-6. https://doi.org/10.1016/S00256196(12)60694-6

4. Rizos C V, Elisaf MS, Liberopoulos EN. Effects of thyroid dysfunction on lipid profile. Open Cardiovasc Med J 2011;5:76-84. https://doi.org/10.217 4/1874192401105010076

5. Milionis HJ, Tambaki AP, Kanioglou CN, Elisaf MS, Tselepis AD, Tsatsoulis A. Thyroid substitution therapy induces high-density lipoprotein-associated platelet- activating factor-acetylhydrolase in patients with subclinical hypothyroidism: a potential antiatherogenic effect. Thyroid 2005;15:45560. https://doi.org/10.1089/thy.2005.15.455

6. Toruner F, Altinova AE, Karakoc A, Yetkin I, Ayvaz G, Cakir N, et al. Risk factors for cardiovascular disease in patients with subclinical hypothyroidism. Adv Ther 2008;25:430. https://doi. org/10.1007/s12325-008-0053-7

7. Ates I, Yilmaz FM, Altay M, Yilmaz N, Berker D, Güler $S$. The relationship between oxidative stress and autoimmunity in Hashimoto"s thyroiditis. Eur J Endocrinol 2015;173(6):791-9. https://doi. org/10.1530/EJE-15-0617

8. Torun AN, Kulaksizoglu S, Kulaksizoglu M, Pamuk BO, Isbilen E, Tutuncu NB. Serum total antioxidant status and lipid peroxidation marker malondialdehyde levels in overt and subclinical hypothyroidism. Clin Endocrinol (Oxf) 2009;70:469-74. https://doi.org/10.1111/j.1365-2265.2008.03348.x

9. Pereira B, Rosa LC, Safi DA, Bechara EJH, Curi R. Control of superoxide dismutase, catalase and glutathione peroxidase activities in rat lymphoid organs by thyroid hormones. J Endocrinol 1994;140:73-7. https://doi.org/10.1677/ joe. 0.1400073

10. Swaroop A, Ramasarma T. Heat exposure and hypothyroid conditions decrease hydrogen peroxide generation in liver mitochondria. Biochem J 1985;226:403-8. https://doi.org/10.1042/ bj2260403

11. Yilmaz S, Ozan S, Benzer F, Canatan H. Oxidative damage and antioxidant enzyme activities in experimental hypothyroidism. Cell Biochem Funct 2003;21(4):325-30. https://doi.org/10.1002/ cbf. 1031

12. Dumitriu L, Bartoc R, Ursu $H$, Purice $M$, lonescu $V$. Significance of high levels of serum malonyl dialdehyde (MDA) and ceruloplasmin (CP) in hyper-and hypothyroidism. Endocrinologie 1988;26:35-8.

13. Costantini F, Pierdomenico SD, Cesare D De, De Remigis P, Bucciarelli T, Bittolo- Bon G, et al. Effect of thyroid function on LDL oxidation. Arterioscler Thromb Vasc Biol 1998;18:732-7. https://doi. org/10.1161/01.ATV.18.5.732

14. Bacchetti T, Ferretti G, Sahebkar A. The role of paraoxonase in cancer. Semi Cancer Biol 2019; 56:72-86. https://doi.org/10.1016/j.semcancer.2017.11.013

15. Aviram M, Rosenblat M, Bisgaier CL, Newton RS, Primo-Parmo SL, La Du BN. Paraoxonase inhibits high-density lipoprotein oxidation and preserves its functions. A possible peroxidative role for paraoxonase. J Clin Invest 1998;101:1581-90 https:// doi.org/10.1172/JCl1649

16. Mackness MI. "A"-esterases: Enzymes looking for a role? Biochem Pharmacol 1989;38:385-90. https://doi.org/10.1016/0006-2952(89)90376-6

17. Gan KN, Smolen A, Eckerson HW, La Du BN. Purification of human serum paraoxonase/arylesterase. Evidence for one esterase catalyzing both activities. Drug Metab Dispos 1991;19:100-6.

18. Baskol G, Atmaca H, Tanrıverdi F, Baskol M, Kocer D, Bayram F. Oxidative stress and enzymatic antioxidant status in patients with hypothyroidism before and after treatment. Exp Clin Endocrinol Diabetes 2007;115:522-6. https://doi. org/10.1055/s-2007-981457

19. Ayub A, Mackness MI, Arrol S, Mackness B, Patel J, Durrington PN. Serum paraoxonase after myocardial infarction. Arterioscler Thromb Vasc Biol 1999;19:330-5. https://doi.org/10.1161/01. ATV.19.2.330

20. Mackness MI, Harty D, Bhatnagar D, Winocour $\mathrm{PH}$, Arrol S, Ishola M, et al. Serum paraoxonase activity in familial hypercholesterolaemia and insulin-dependent diabetes mellitus. Atherosclerosis 1991;86:193-9. https://doi.org/10.1016/00219150(91)90215-O

21. Sahin M, Bobusoglu O, Yetim A, Ates F. Paraoxonase-1 and arylesterase levels in patients with ul- 
cerative colitis. Arab J Gastroenterol 2019;20:148. https://doi.org/10.1016/j.ajg.2019.01.009

22. Erel O. A novel automated method to measure total antioxidant response against potent free radical reactions. Clin Biochem 2004;37:112-9. https:// doi.org/10.1016/j.clinbiochem.2003.10.014

23. Erel O. A new automated colorimetric method for measuring total oxidant status. Clin Biochem 2005;38:1103-11. https://doi.org/10.1016/j.clinbiochem.2005.08.008

24. Akcilar R, Akcilar A, Savran B, Ayada C, Koçak C, Koçak FE, et al. Effects of ukrain in rats with intestinal ischemia and reperfusion. J Surg Research 2015;195(1):67-73. https://doi.org/10.1016/j. jss.2014.12.040

25. Eckerson HW, Wyte CM, La Du BN. The human serum paraoxonase/arylesterase polymorphism. Am J Hum Genet 1983;35(6):1126-38.

26. Ates I, Altay M, Yilmaz FM, Topcuoglu C, Yilmaz $\mathrm{N}$, Guler S. Is oxidative stress an effective risk factor in the development of overt hypothyroidism in Hashimoto"s thyroiditis. In 17th European Congress of Endocrinology 2015; vol. 37, BioScientifica. https://doi.org/10.1530/endoabs.37.EP944
27. Ates I, Altay M, Yılmaz FM, Topçuoğlu C, Yılmaz N, Berker D, et al. The impact of levothyroxine sodium treatment on oxidative stress in Hashimoto"s thyroiditis. Eur J Endocrinol 2016;174(6):727-34. https://doi.org/10.1530/EJE-15-1061

28. Aydogdu A, Karakas EY, Erkus E, Altıparmak $\mathrm{iH}$, Savık E, Ulas T, et al. Epicardial fat thickness and oxidative stress parameters in patients with subclinical hypothyroidism. Arch Med Sci 2017;13(2):383-9. https://doi.org/10.5114/ aoms.2017.65479

29. Cebeci E, Alibaz-Oner F, Usta M, Yurdakul S, Erguney M. Evaluation of oxidative stress, the activities of paraoxonase and arylesterase in patients with subclinical hypothyroidism. J Investig Med 2012;60:23-8. https://doi.org/10.2310/ JIM.0b013e31823581dd

30. Santi A, Duarte MM, de Menezes CC, Loro VL. Association of lipids with oxidative stress biomarkers in subclinical hypothyroidism. Int $\mathrm{J}$ Endocrinol 2012;2012:856359. https://doi. org/10.1155/2012/856359
CONFLICT OF INTEREST

Authors declare no conflict of interest. GRANT SUPPORT AND FINANCIAL DISCLOSURE None declared.

\section{AUTHORS' CONTRIBUTION}

The following authors have made substantial contributions to the manuscript as under:

\section{Conception or Design:}

Acquisition, Analysis or Interpretation of Data:

Manuscript Writing \& Approval:

All the authors agree to be accountable for all aspects of the work in ensuring that questions related to the accuracy or integrity of any part of the work are appropriately investigated and resolved.

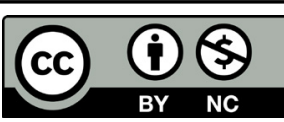

Copyright (C) 2021. Mustafa Yontem, et al. This is an Open Access article distributed under the terms of the Creative Commons Attribution-NonCommercial 4.0 International License, which permits unrestricted use, distribution \& reproduction in any medium provided that original work is cited properly. 